\title{
REPORT ON CATTU 1986 ANNUAL GENERAL MEETING
}

The 1986 annual general meeting (AGM) of the Canadian Association of Teachers of Technical Writing was held at the University of Manitoba on May 28, 1986, as part of the society's third annual conference. Approximately 40 members were in attendance and the meeting was chaired by society president Ron Blicq (Red River Community College). The notes below summarize the main points.

1. Annual membership, which had been climbing only slowly during the past year, took a sudden spurt following letters sent in November by the Technostyle editor to universities and colleges across Canada. Immediately before the AGM, membership totalled 87 members.

2. Jennifer Connor, Technostyle editor (University of Western Ontario), reported that she and Associate Editor, Alice Gibson (University of Western Ontario), began producing the journal at Western as soon as they received 1985 CATTW conference papers. According to members' wishes, the editors changed the format of Technostyle, and they shortened the production schedule to catch up the two issues which were behind in publication.

She noted that over the year only three new submissions were received and sent to the new editorial committee for review. She appealed to members to submit articles, notes and reviews, and requested that extracts of AGM reports be submitted for publication annually in Technostyle.

Finally, she reported that Technostyle began a journal exchange with our sister society in the United States, ATTW, and that she will soon apply for copyright to be held by CATTW.

3. Bob Gosselink, CATTW secretary-treasurer (University of Waterloo), reported by mail that CATTW funds had improved from a balance of $\$ 46.00$ on May 31,1985 to a balance of $\$ 1060.70$ on May 28, 1986, brought about primarily by an increase in membership. (The balance should have been about $\$ 250$ higher, except that many renewal membership fees were still outstanding.) Society operating costs-principally production and printing of Technostyle--were offset by a grant of $\$ 2037$ from the Department of Secretarial and Administrative Studies of the University of Western Ontario.

4. The program committee was elected for the 1987 conference, which will be held on May 28 and 29 at McMaster University in Hamilton, Ontario. Society Vice-president Jacqueline Bossë-Andrieu (Université d'Ottawa) will chair the committee and will have Ruth Ellen Greenwood (Humber College) and Bruce Lundgren (University of 
Western Ontario) to assist her. Ruth Ellen Greenwood was also appointed to be the CATTW local representative for the 1987 Learned Society planning committee.

5. A nominating committee was elected to assist committee chairperson Joan L. Pavelich (University of British Columbia). The two new members are Betty Urquhart (Fraser Valley College) and Louise Desaulniers (Université de Montréal).

6. A slightiy revised CATTW constitution, incorporating changes recommended at the 1985 AGM, was approved and Jacqueline Bossé-Andrieu agreed to translate it into French. Ron Blicq agreed to have the dual-language constitution retyped and printed.

7. A proposal to form a committee to carry out a second survey of teachers of technical writing in Canada, which had been carried forward from the 1985 AGM, was deferred for another year.

8. Past President Joan L. Pavelich was created a CATTW Life Member in recognition of her untiring efforts to create and steer CATTW in its formative years, and was presented with a silver platter with the inscription: "Joan L. Pavelich, Life Member CATTW, 1986."

9. A vote of thanks was recorded for the tremendous support accorded the CATTW by the Department of Secretarial and Administrative Studies, University of Western Ontario, in the production and printing of Technostyle. A second vote of thanks was recorded for the assistance provided by Red River Community College, Winnipeg, in the production and printing of society correspondence paper and the conference program. Ron Blicq agreed to write to both institutions, acknowledging their support.

At an informal meeting held on May 29, the CATTW executive also agreed to form an ad hoc committee to investigate the possibility of CATTW coordinating the development, administration and presentation of seminars, workshops and courses on technical writing for engineers and technical people in mainland China. Michael Godfrey (Dawson College, Montreal) and Lil Rodman (University of British Columbia) were asked to form the committee, with the former in the chair.

Following the meeting, the members attended a reception sponsored by the University of Manitoba.

Prepared by:

Ron S. Blicq

Red River Community College 